\title{
Time-Kill Kinetics of Lipid Fractions Isolated from Condiments against Foodborne Pathogens
}

\section{Ayeza Naeem ${ }^{1 *}$, Tanveer \\ Abbas', Tahira Mohsin \\ Ali $^{2}$ and Abid Hasnain ${ }^{2}$}

'Department of Microbiology, University of Karachi, Main University Road, Karachi, 75270 Sindh, Pakistan 2Department of Food Science and Technology, University of Karachi, Main University Road, 75270 Sindh, Pakistan

Received: 12 October 2017 Accepted: 2 March 2018
*Corresponding author:

E-mail: ayeza.naeem@gmail.com

\begin{abstract}
SUMMARY
Lipid fractions that are extracted from condiments have a wide array of biological potential and are commonly utilized for medicinal and culinary applications. This investigation aims at determining the antimicrobial potential of lipid fractions isolated using two different solvent systems against five foodborne pathogens. The antibacterial efficacy was tested after $0,1,2,3$ and $24 \mathrm{~h}$ of incubation with the active agent. The leakage of cellular content was assessed at 1 and $2 \mathrm{~h}$ of incubation. Scanning electron microscope (SEM) images were obtained after $18 \mathrm{~h}$ of contact time with lipid fractions at their minimum inhibitory concentration (MIC). From the results obtained from time-kill and cell constituents release tests, it could be concluded that during 3 and $1 \mathrm{~h}$ of incubation, the lipid fractions were more potent against Gram-negative isolates (Escherichia coli ATCC 8739). However, prolonged incubation with the active agent inhibited Gram-positive isolate, i.e. Listeria monocytogenes ATCC 13932. SEM images of treated microorganisms also confirmed the inhibitory action of selected lipid fractions against all the tested pathogens. The cellular morphology of the bacteria was completely altered after $18 \mathrm{~h}$ of incubation with the lipid fractions. The results of the present study corroborate significant inhibitory effects and disruption in bacterial cell integrity following prolonged incubation with these lipid fractions. The results also affirm the use of the tested lipid fractions in food systems.
\end{abstract}

Key words: time-kill kinetics, scanning electron microscopy, cell constituent release, foodborne pathogens

\section{INTRODUCTION}

Pathogens are ubiquitous and are associated with every phase of human life. Bacteria with a potential to cause severe ailments are found in soil, water bodies or even in our food items and may cause life-threatening illnesses in humans. Therefore, to prevent any such instances recent techniques in the field of food technology and microbiology have been applied to ensure consumer safety and a safer food supply. In the past few decades, the cases of foodborne infections have increased dramatically due to utilization of undercooked and minimally processed ready-to-eat products, including hot dogs, salami, sausages, dairy products, primarily ice cream, or fruits and vegetables (1). Propagation of bacteria during low temperature storage, contamination by pathogens and their resistance to disinfection are alarming issues regarding minimally processed products, since these items are utilized without any prior treatment or processing (2). Grazing animal and poultry meat may be a source of foodborne pathogens. Feed supplements that are basically animal byproducts may also act as a carrier to transfer microorganisms to other animals. On the other hand, fertilization of fruits and vegetables with untreated manure can also contaminate soil or water supplies with pathogens. The contaminated water supply may also transmit bacteria or food viruses, which include Listeria, Salmonella, Clostridium, Yersinia, Campylobacter, Shigella and hepatitis $\mathrm{A}$. These pathogens may be present in low numbers or even in low infectious doses (10-1000 bacterial cells). Due to increasing awareness of food safety issues such as foodborne ailments and their implications, consumers have become much more aware of 
the health concerning problems. Disinfection using artificially synthesized antimicrobial agents is often utilized for minimally processed foods (MPF) to protect the product, but these compounds possess some adverse effects and have limitations in their usage, such as low antibacterial potency and may result in the development of cancers (3). The inability of these chemicals to eliminate microorganisms from fruits and vegetables may be due to plethora of factors: hydrophobicity of the waxy cuticle of vegetables and fruits, which prevents the disinfectant from reaching the surface; the formation of biofilms that can protect the microorganism from the lytic effects of such agents; and inactivation of these disinfectants when they come into contact with the host tissues. Therefore, to achieve food safety, there is an elevated consumer demand for substituting artificially synthesized antibacterial agents with natural alternatives (4). The benefit of natural antimicrobial agents is that they have a wide spectrum of application without toxic effects on humans, improved sensory attributes and the ability to extend storage life of MPF (5). Earlier studies have indicated that bay leaf (Laurus nobilis), black cumin (Nigella sativa) seeds, fennel (Foeniculum vulgare Mill.) seeds and coriander (Coriandrum sativum) seeds possess antibacterial activity against pathogenic and food spoilage pathogens (6-9). In vitro studies have elaborated that lipid fractions have promising antibacterial potential. However, when these lipid fractions are applied to food matrices directly, relatively larger quantity of these active agents is required, making them organoleptically unacceptable (10). To avoid such instances, these lipid fractions need to be nanosized or encapsulated to balance antimicrobial potency and sensory acceptability (11). The objectives of this study are to report the time-kill kinetics of lipid fractions against five food isolates, i.e. Escherichia coli ATCC 8739, Listeria monocytogenes ATCC 13932, Vibrio parahaemolyticus ATCC 17802, Bacillus cereus ATCC 11778 and Vibrio alginolyticus ATCC 17749 when treated with lipid fractions obtained from two different solvent systems. Cell constituent release measured spectrophotometrically at 260 $\mathrm{nm}$ and scanning electron microscopy of treated and untreated (control) bacterial isolates were also compared to evaluate the potency of these antibacterial agents for application in food matrices without any possible hazards.

\section{MATERIALS AND METHODS}

\section{Materials}

Sodium chloride, phosphate-buffered saline, tryptone soy broth (TSB), Müller-Hinton agar (MHA) and broth were purchased from Thermo Fisher Scientific Oxoid Ltd. (Basingstoke, Hampshire, UK) and dimethyl sulfoxide from Fisher BioReagents (Roskilde, Denmark) were used in this study.

\section{Extraction of lipid fractions}

The dried herbs were collected from a local grocery store in Karachi, Pakistan $\left(25.0700^{\circ} \mathrm{N}, 67.2848^{\circ} \mathrm{E}\right)$ and the tested lipid fractions were obtained using the solvent extraction system according to the method of Cheikh-Rouhou et al. (12). The main aim was to evaluate the antibacterial potential of culinary herbs including bay leaf (Lauraceae family), black cumin (Ranunculaceae family), fennel seeds and coriander seeds (Umbellifer family) against foodborne pathogens. These herbs were selected due to the ease of their availability and common use as food ingredients. The lipid fractions used in this study were methanolic and ethanolic lipid fractions of fennel seeds, black cumin seeds, bay leaf and coriander seeds. The lipid fractions were extracted fresh to preserve the antibacterial potency and stored at freezing temperature until analyzed.

\section{Concentration of lipid fractions used in time-kill assay}

The selected lipid fractions did not yield results against all the tested microorganisms reported by Naeem et al. (13). Only those lipid fractions that gave antibacterial activity against the tested pathogens were selected for this research. The MICs of selected lipid fractions against food pathogens are shown in Table 1 (13).

\section{Bacterial cultures}

Test microorganisms were foodborne pathogens, i.e. Escherichia coli ATCC 8739, Listeria monocytogenes ATCC 13932, Vibrio parahaemolyticus ATCC 17802, Bacillus cereus ATCC 11778 and Vibrio alginolyticus ATCC 17749, and were procured from Food Safety Research Laboratory, Department of Microbiology, University of Karachi, Pakistan. Each assay was carried out in three batches.

\section{Time-kill studies}

In vitro determination of antibacterial activity of lipid fractions included total viable count of the tested pathogens after the supplementation of the lipid fractions at minimum inhibitory concentration (MIC) according to the method of Hsouna et al. (14). For time-kill assay, test tubes containing bacterial cultures (approx. $10^{8} \mathrm{CFU} / \mathrm{mL}$ ) were inoculated with eight different lipid fractions at their MICs against respective bacteria. The concentrations of lipid fractions ranged from 62.5 to $1000 \mu \mathrm{g} / \mathrm{mL}$. The dilutions of the used lipid fractions were prepared in $40 \%$ dimethyl sulfoxide (DMSO). The volume was made up to $5 \mathrm{~mL}$ using physiological saline solution $(0.8 \%)$. After contact time of $0,1,2,3$ and $24 \mathrm{~h}, 100 \mu \mathrm{L}$ of the sample were transferred to $900 \mu \mathrm{L}$ of sterile saline solution. Subsequently, $0.1 \mathrm{~mL}$ of this diluted sample was spread on the surface of solidified Müller-Hinton agar plates. The control and test plates were incubated at $37^{\circ} \mathrm{C}$ and bacterial counts were enumerated. The negative control, i.e. $40 \%$ DMSO, was also run using the same protocol.

\section{Cell constituent release}

The release of intracellular components was measured spectrophotometrically at $260 \mathrm{~nm}$ by the method of Di Pasqua et al. (15). Working cultures of bacterial isolates were ob- 
Table 1. Minimum inhibitory concentration (MIC) of lipid fractions against foodborne pathogens

\begin{tabular}{|c|c|c|c|c|c|c|c|c|}
\hline \multirow{2}{*}{ Food pathogen tested } & \multicolumn{8}{|c|}{$\gamma(\mathrm{MIC}) /(\mu \mathrm{g} / \mathrm{mL})$} \\
\hline & $\mathrm{MN}$ & EN & MF & $\mathrm{EF}$ & MC & EC & MB & EB \\
\hline Escherichia coli ATCC 8739 & 500 & 250 & $\mathrm{~N} / \mathrm{D}$ & $\mathrm{N} / \mathrm{D}$ & 250 & 1000 & 250 & 250 \\
\hline Listeria monocytogenes ATCC 13932 & 250 & 1000 & 1000 & 250 & 250 & 1000 & 250 & 500 \\
\hline Vibrio parahaemolyticus ATCC 17802 & $\mathrm{~N} / \mathrm{D}$ & 250 & $\mathrm{~N} / \mathrm{D}$ & $\mathrm{N} / \mathrm{D}$ & $\mathrm{N} / \mathrm{D}$ & 1000 & 250 & $\mathrm{~N} / \mathrm{D}$ \\
\hline Vibrio alginolyticus ATCC 17749 & 250 & 250 & $\mathrm{~N} / \mathrm{D}$ & 500 & $\mathrm{~N} / \mathrm{D}$ & 1000 & $\mathrm{~N} / \mathrm{D}$ & 250 \\
\hline Bacillus cereus ATCC 11778 & 250 & 250 & 1000 & $\mathrm{~N} / \mathrm{D}$ & $\mathrm{N} / \mathrm{D}$ & 500 & 250 & 1000 \\
\hline
\end{tabular}

$\mathrm{N} / \mathrm{D}=$ No detection of antimicrobial activity hence no MIC. MN, MF, MC, MB, EN, EF, EC and EB stand for methanolic and ethanolic lipid fractions of black cumin, fennel seeds, coriander seeds and bay leaf, respectively. Reproduced from Naeem et al. (13)

tained. After centrifugation (Multifuge $\mathrm{e}^{\mathrm{TM}} 1 \mathrm{~S}$ centrifuge; Heraeus, Neston, Cheshire, UK) at $3000 \times g$ for $15 \mathrm{~min}$, the cells were washed thrice and transferred to phosphate-buffered saline. The cell suspension (100 mL) was added to lipid fractions at their MICs and incubated in an orbital shaker (ES-20; CBM-Scientific, West Lothian, Scotland, UK) maintained at $150 \mathrm{rpm}$ and $(35 \pm 2)^{\circ} \mathrm{C}$. A control was also prepared using the same method but with the absence of lipid fractions. After 1 and $2 \mathrm{~h}$ of incubation period, $10 \mathrm{~mL}$ of the sample were filter-sterilized through 0.2- $\mathrm{MM}$ pore size Corning (Sigma-Aldrich, Merck KGaA, Darmstadt, Germany) membrane filter. The effect of lipid fraction on the integrity of cell wall was determined by measuring the absorbance of the filtrate at $260 \mathrm{~nm}$ using UV-Vis spectrophotometer (1240 Mini; Shimadzu, Tokyo, Japan). The test tubes with tested bacteria without lipid fractions were used as a control. The blank control was sterile physiological saline.

\section{Scanning electron microscopy}

The morphological changes in selected bacteria treated with lipid fractions were determined using scanning electron microscopy (SEM) analysis. Selected foodborne pathogens, namely Escherichia coli ATCC 8739, Listeria monocytogenes ATCC 13932, Vibrio parahaemolyticus ATCC 17802, Bacillus cereus ATCC 11778 and Vibrio alginolyticus ATCC 17749, were incubated in tryptone soya broth at $37^{\circ} \mathrm{C}$ for $18 \mathrm{~h}$. The bacterial count was $1.5 \cdot 10^{8} \mathrm{CFU} / \mathrm{mL}$. Lipid fractions were supplemented at their $1 / 2$ MICs to centrifuge tubes and labelled as treated. Control tubes having bacterial suspensions were also run alongside. All suspensions were incubated at $37^{\circ} \mathrm{C}$ for $18 \mathrm{~h}$. The cells were dehydrated using 70,80 and $90 \%$ ethanol for 10 min each. After dehydration, the specimens were coated with gold in an ion coater up to $300 \AA$ using smart coater with an ion sputtering device (model JFC-1500) and energy-dispersive X-ray spectroscopy detector (model EX-54175JMU; JEOL, Tokyo, Japan). Finally, the disruption in bacterial cell morphology was observed with a SEM (JSM-6380A; JEOL) at Centralized Science Laboratories, University of Karachi, Pakistan.

\section{Statistical analysis}

Analysis of variance (ANOVA) was used to calculate significant differences between the mean values. Duncan's test $(p \leq 0.05)$ was used to separate the mean values by employing SPSS software v. 23 (16).

\section{RESULTS AND DISCUSSION}

\section{Bactericidal mechanism}

The time-kill assay of MIC of respective lipid fraction against food isolates was performed (Fig. 1-Fig. 5). Generally, all the ethanolic lipid fractions had MIC of $62.5 \mu \mathrm{g} / \mathrm{mL}$, which is the lowest concentration ever reported to be tested against selected foodborne pathogens. However, when these MICs were tested through agar well diffusion assay, the same concentration of lipid fractions failed to generate any such results. The difficulty in diffusion through the agar matrix may be the possible reason for not producing positive results. Ethanolic lipid fractions of bay leaf and black cumin seeds inhibited all the tested food pathogens, indicating that they are highly rich in antimicrobial components. Lipid fractions of black cumin and bay leaf were successful in inhibiting a wide range of pathogens when tested in vitro. The data of time-kill assay indicate that the lowest log CFU/mL was observed of Listeria monocytogenes ATCC 13932 when treated with methanolic extracts of lipid fraction of coriander seeds at $1000 \mu \mathrm{g} / \mathrm{mL}$ after $24 \mathrm{~h}$ of incubation. The reason behind this activity may be the chemical composition of the outer cell membrane of Gram-negative bacteria. It provides the hydrophilic attribute to the bacterial surface, thereby acting as a potent perme-

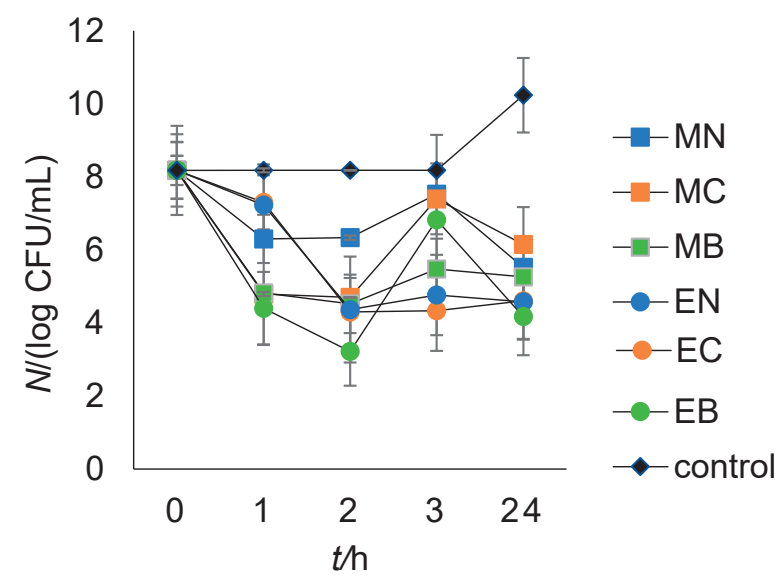

Fig. 1. Effect of different lipid fractions on the viability of Escherichia coli ATCC 8739. The vertical bars represent the standard error of mean values of three replicates. MN, MC, MB, EN, EC and EB stand for methanolic and ethanolic extracts of lipid fractions of black cumin, coriander seeds and bay leaf, respectively, at their minimum inhibitory concentrations (MICs) 


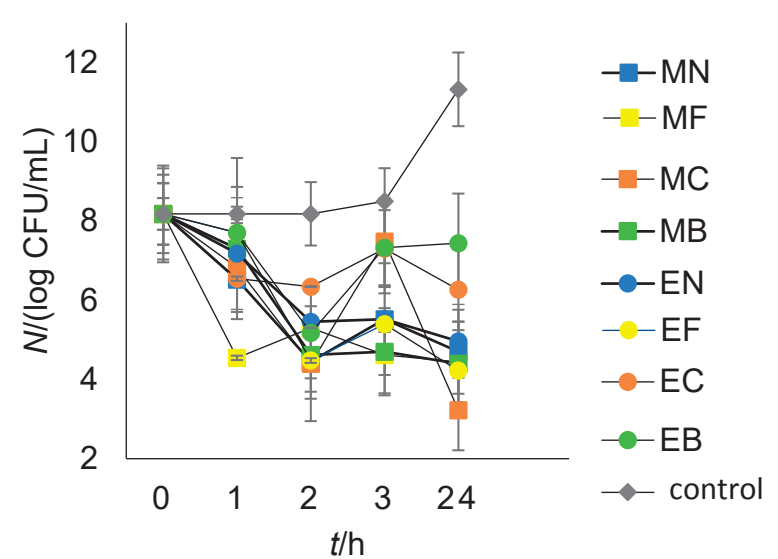

Fig. 2. Effect of different lipid fractions on the viability of Listeria monocytogenes ATCC 13932. The vertical bars represent the standard error of mean values of three replicates. MN, MF, MC, MB, EN, EF, EC and $\mathrm{EB}$ stand for methanolic and ethanolic extracts of lipid fractions of black cumin, fennel seeds, coriander seeds and bay leaf, respectively, at their minimum inhibitory concentrations (MICs)

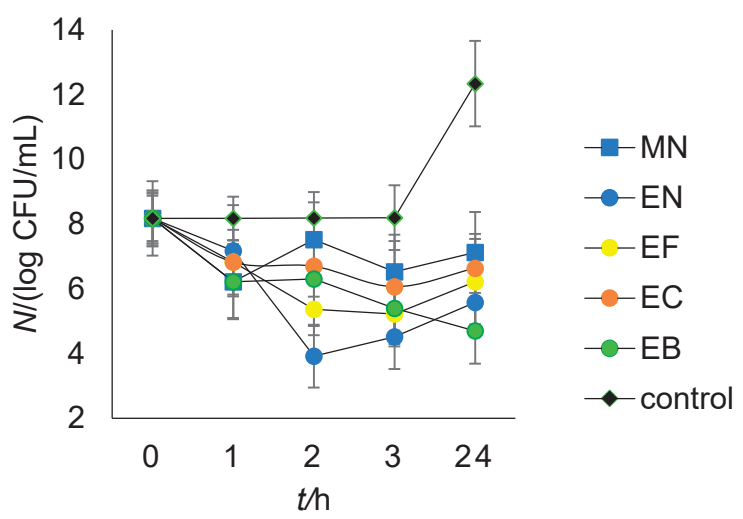

Fig. 3. Effect of different lipid fractions on the viability of Vibrio alginolyticus ATCC 17749. The vertical bars represent the standard error of mean values of three replicates. MN, EN, EF, EC and EB stand for methanolic extract of lipid fraction of black cumin and ethanolic extracts of lipid fractions of black cumin, fennel seeds, coriander seeds and bay leaf, respectively, at their minimum inhibitory concentrations (MICs)

ability hurdle to different molecules (10). As Gram-positive bacteria lack this outer envelope, the hydrophobic components of lipid fractions had a direct interaction with the phospholipid bilayer of the cellular envelope generating their action, resulting either in elevated ion exchange and leakage of important intracellular components, or in dysfunction of enzymatic pathways in bacterial cells (17). However, after $3 \mathrm{~h}$ of incubation, the lowest bacterial count was observed of $E$. coli ATCC 8739 when tested against ethanolic lipid fraction of coriander. Time-kill kinetic studies showed that all the treated food isolates had similar trend of inhibition, i.e. maximum inhibition was observed after $2 \mathrm{~h}$ of incubation when lipid fractions were supplemented in the media. After $3 \mathrm{~h}$, rise in bacterial count was observed followed by drop in the cell

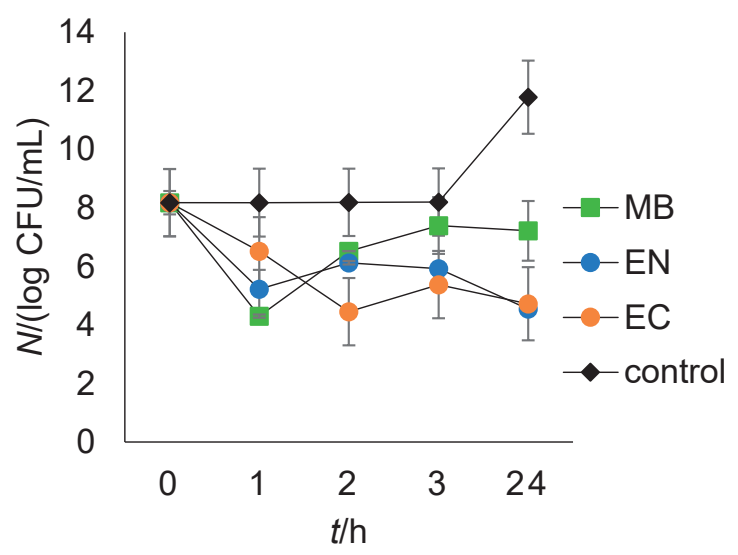

Fig. 4. Effect of different lipid fractions on the viability of Vibrio parahaemolyticus ATCC 17802. The vertical bars represent the standard error of mean values of three replicates. MB, EN and EC stand for methanolic extract of lipid fraction of bay leaf, and ethanolic extracts of lipid fractions of black cumin and coriander seeds, respectively, at their minimum inhibitory concentrations (MICs)

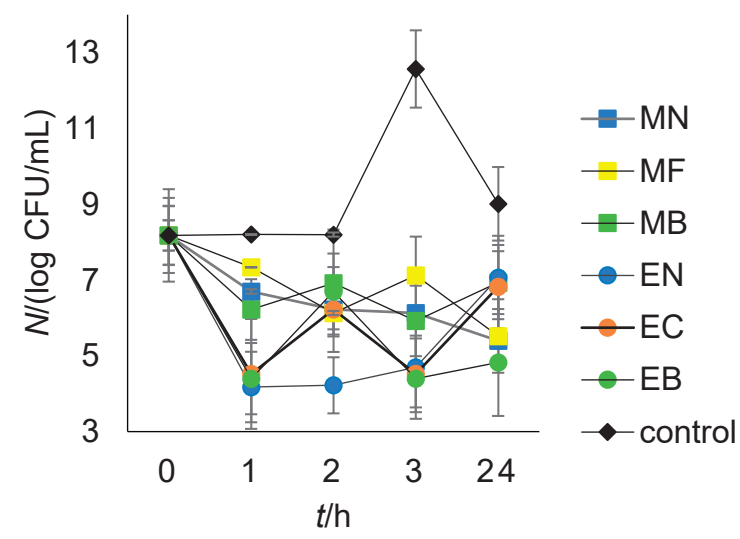

Fig. 5. Effect of different lipid fractions on the viability of Bacillus cereus ATCC 11778. The vertical bars represent the standard error of mean values of three replicates. MN, MF, MB, EN, EC and EB stand for methanolic extracts of lipid fractions of black cumin, fennel seeds and bay leaf, and ethanolic extracts of lipid fractions of black cumin, coriander seeds and bay leaf, respectively, at their minimum inhibitory concentrations (MICs)

numbers after prolonged $24 \mathrm{~h}$ of incubation. However, bacterial counts increased in the control tubes. It could be concluded from this observation that the inhibitory phase of these lipid fractions was within $2 \mathrm{~h}$, but after $24 \mathrm{~h}$ of incubation, the cells were inhibited due to extended contact with these lipid fractions. The most potent lipid fraction found from the results obtained from TVC after $24 \mathrm{~h}$ of incubation was that of bay leaf against nearly all the tested pathogens. When comparing the results of methanolic and ethanolic lipid fractions, it can also be concluded that the ethanolic lipid fractions were more potent in reducing the bacterial counts of all the tested food pathogens. The reason behind this activity is the ability of ethanol solvent to extract a large number of antioxidants, total phenolic and total flavonoid compounds. Due to higher concentration of 
these compounds, which are the main contributors to antibacterial potential, higher antimicrobial activity is demonstrated by ethanolic lipid fractions (18). It is a well acknowledged fact that higher concentration of lipid fraction is needed to inhibit bacteria in food matrices than in laboratory media. Due to alterations in the organoleptic attributes of food, it would not be feasible to supplement a sufficient concentration of lipid fraction to have bactericidal effect. However, lower concentrations that lead to bacteriostatic conditions are enough for the food safety if the contaminating bacteria are low in numbers. The results reported in this study indicated that these lipid fractions are inhibitory at low concentration of $62.5 \mu \mathrm{g} / \mathrm{mL}$, which would not interfere with the organoleptic attributes if incorporated in the packaging material of minimally processed foods. Escherichia coli ATCC 8739, Listeria monocytogenes ATCC 13932, Vibrio parahaemolyticus ATCC 17802, Bacillus cereus ATCC 11778 and Vibrio alginolyticus ATCC 17749 are the most important pathogens of great concern to food industry. Vibrio alginolyticus is present in seafood (19) and may cause gastrointestinal tract disorders upon ingestion of improperly cooked food items. E. coli and $L$. monocytogenes are commonly present in water and food items that are contaminated and did not receive any processing prior their consumption (20), whereas B. cereus may be present in rice and leftovers which are not stored at temperatures optimal for shelf life (21). As all these pathogens can cause life-threatening diseases, it is necessary to identify doses of natural antimicrobial agents to combat them without any toxic side effects.

\section{Cellular constituent leakage}

In this study, a significant increase in the cellular constituent leakage was observed when treating the tested bacteria with lipid fractions at their MICs compared to control (untreated). After 120 min of incubation with different lipid fractions, increase in the absorbance of the filtrates obtained from all the tested bacterial cells was observed (Table 2). When Student's $t$-test was applied to compare the activity of methanolic and ethanolic lipid fractions, data were found to be statistically significant. This indicates that there were no differences between both groups. This increase was lower in control samples. Therefore, it is concluded that the antibacterial mechanism of lipid fractions starts with the disruption of the cellular envelopes, followed by loss in intracellular constituents, which ultimately caused cell death. At 60 min of incubation, leakage of intracellular components was the highest in E. coli ATCC 8739 when it was treated with ethanolic lipid fraction of black cumin. However, the highest constituent release after $120 \mathrm{~min}$ of contact time was observed with Listeria monocytogenes ATCC 13932 when treated with lipid fraction of bay leaf. These observations showed that the longer the time of contact of bacterial cells with lipid fractions, the higher the inhibitory effects observed on bacterial cells with subsequent cell lysis.

The cellular constituents that are leaked and are detected at $260 \mathrm{~nm}$ from the filtered residues of food isolates can be utilized to assess the antibacterial potential of lipid fractions against foodborne pathogens (22). In this study, increase in absorbance of the treated samples showed that the release of cell constituents into the broth increased due to cell wall disruption of tested pathogens by lipid fractions. The leakage of intracellular materials may elevate the cell wall permeability. The intracellular ingredients that were lost comprised mainly $\mathrm{Na}^{+}, \mathrm{K}^{+}$and $\mathrm{Ca}^{2+}$. However, in more intense cases, reducing sugars and cellular biomolecules such as nucleic acids and proteins are also lost during this transport. The leakage of these vital components may result in the irreversible destruction of the cellular morphology, which was further confirmed by SEM. The ions including $\mathrm{Na}^{+}, \mathrm{Ca}^{2+}$ and $\mathrm{K}^{+}$are vital for maintaining the adenosine triphosphate (ATP) pool and metabolic regulation, so the transport of solutes can alter the structure of cellular membrane and may have a detrimental effect on the metabolic pathways in cell culminating in cell lysis (23). The molecules that constitute the living components of the cell include nucleic acids and amino acids and are present intracellularly throughout the cell cytoplasm. These molecules play a vital role in the process of translation, transcription and DNA replication, and if these moieties are disrupted, it may have a negative impact on cell physiology (24).

\section{Changes in cellular morphology}

The changes in cell membrane morphology were determined using SEM. The morphology of bacterial cells was completely altered and was observed only in treated cells as compared to untreated/control cells (Fig. 6). Different researchers have reported the effect of different antibacterial essences on tested bacterial isolates (25-28). The untreated cell membranes of all tested microorganisms had even and smooth surfaces. However, destructive changes were observed on the cellular membrane morphology of treated cells. Cells exposed to lipid fractions for $18 \mathrm{~h}$ showed deformities in the structure such as appearance of orifices and fissures, disruption of the cellular membrane, clumping of cells, leakage of intracellular components and breakdown of entire cells. It may give rise to the leakage of nutrients and genetic components $(6,25)$. Only Listeria monocytogenes ATCC 13932 treated with ethanolic lipid fraction of bay leaf at $500 \mu \mathrm{g} / \mathrm{mL}$ showed minor changes in cellular morphology. When comparing the results of antibacterial evaluation (time-kill assay, cell constituent release and SEM) against two Vibrio species tested, it could be depicted from the data that lipid fractions were more potent against Vibrio alginolyticus ATCC 17749. These results strongly support the use of these lipid fractions to prevent Vibrio alginolyticus contamination in seafood with a useful application in export of such food commodities.

In a nutshell, lipid fractions obtained from bay leaf could be a potent antibacterial agent to inhibit all the tested pathogens in vitro. Bay leaf is a commonly used condiment in South Asian cuisines. If this herb lipid fraction is supplemented to food preparations, it will be able to combat Listeria monocytogenes, which is a common food contaminant that causes serious foodborne illnesses, and also enhance sensorial attributes of the food items. 


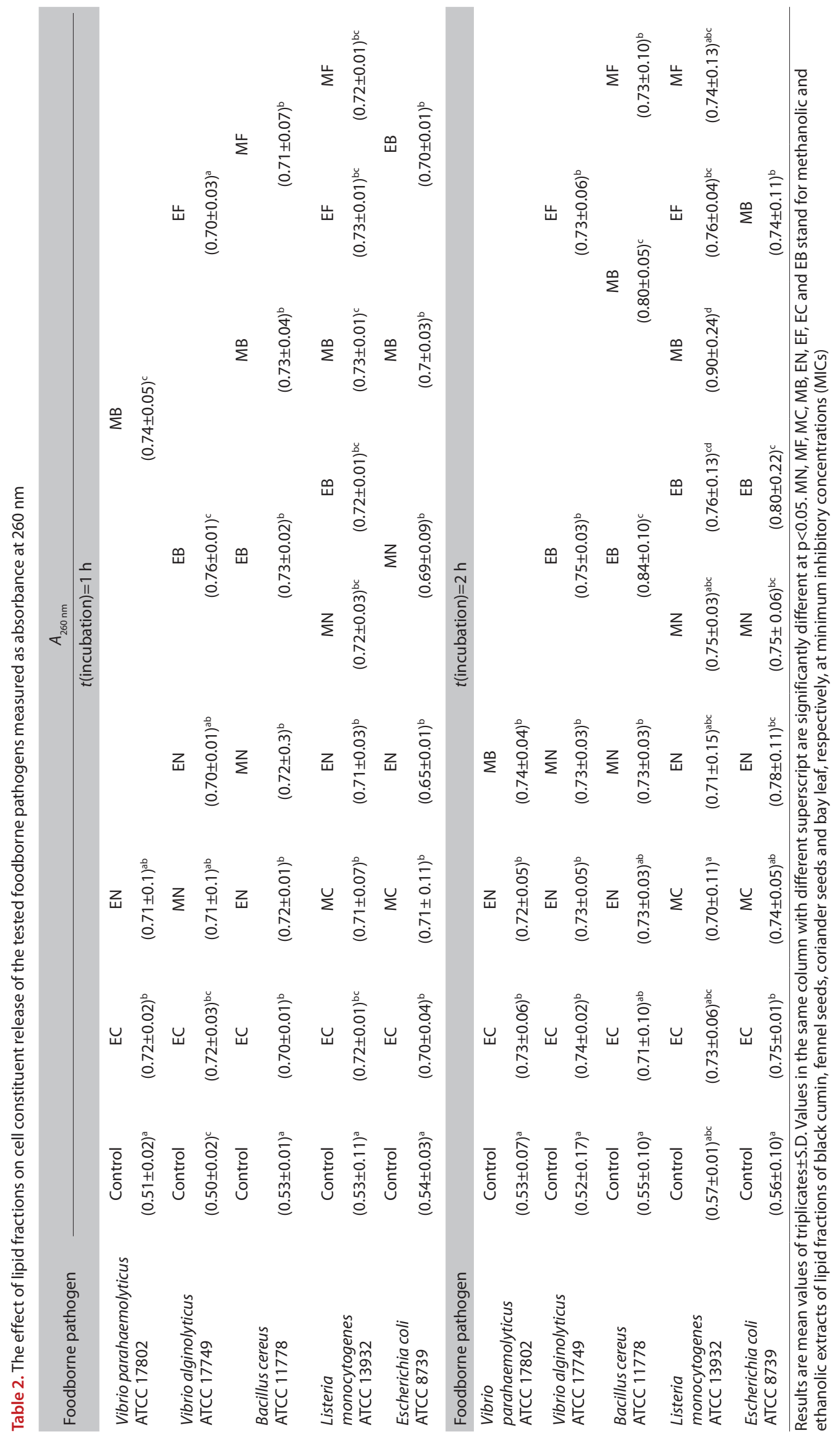



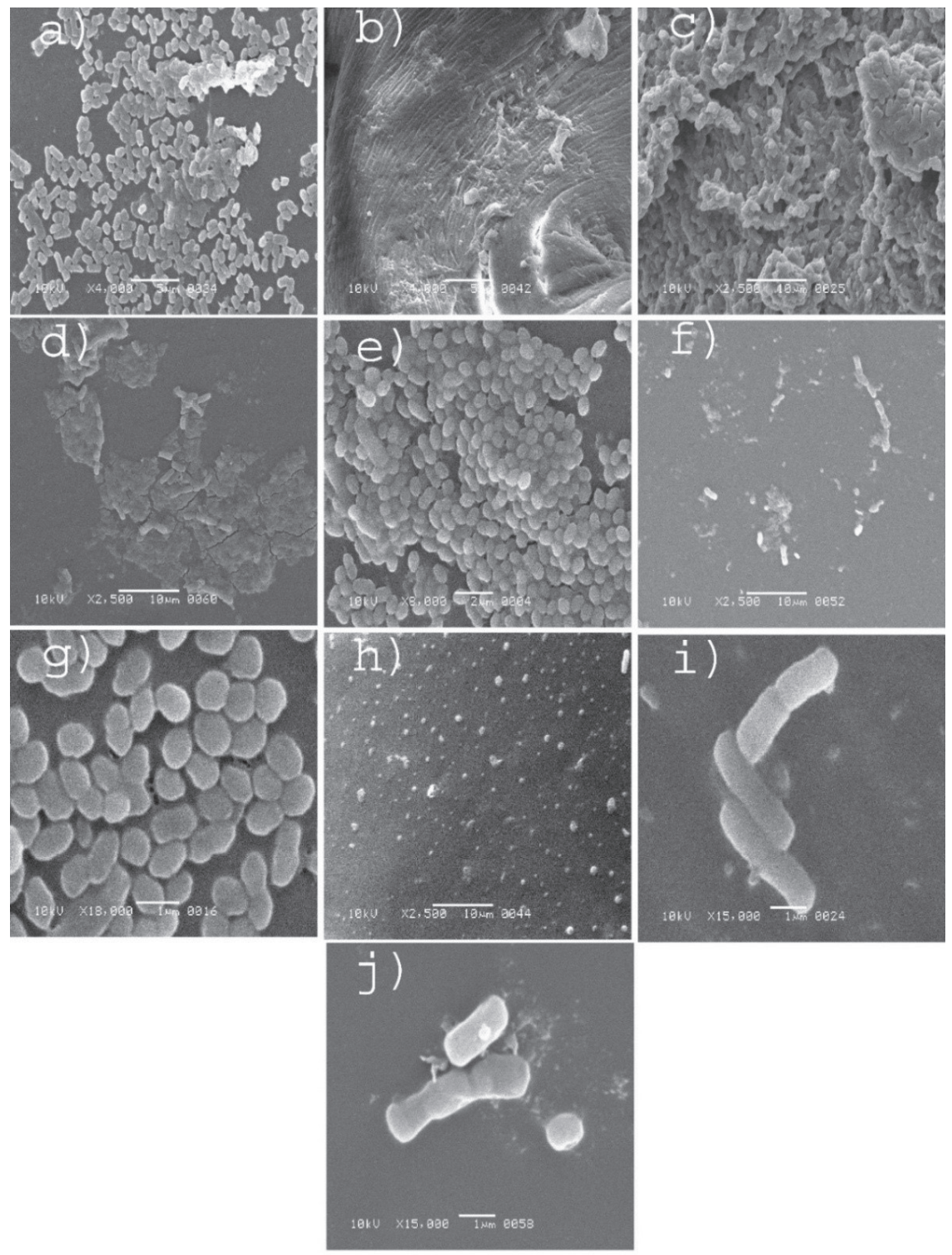

Fig. 6. Scanning electron microscopic images of tested bacteria when treated with lipid fractions at $1 / 2$ minimum inhibitory concentrations (MICs). Escherichia coli ATCC 8739: a) control, b) treated with ethanolic extract of lipid fraction of black cumin at $\gamma=125 \mu \mathrm{g} / \mathrm{mL}$; Bacillus cereus ATCC 11778: c) control, d) treated with ethanolic extract of lipid fraction of black cumin at $\gamma=125 \mu \mathrm{g} / \mathrm{mL}$; Vibrio alginolyticus ATCC 17749: e) control, f) treated with ethanolic extract of lipid fraction of black cumin at $\gamma=125 \mu \mathrm{g} / \mathrm{mL}$; Vibrio parahaemolyticus ATCC 17802: g) control, h) treated with ethanolic extract of lipid fraction of coriander at $\gamma=500 \mu \mathrm{g} / \mathrm{mL}$; and Listeria monocytogenes ATCC 13932: i) control, j) treated with ethanolic extract of lipid fraction of bay leaf at $\gamma=500 \mu \mathrm{g} / \mathrm{mL}$

The results presented in this study are novel due to several reasons: there is no report on the lipid fractions from selected herbs/spices from this geographical location reported here extracted by the solvent extraction method used in this study; the antibacterial potency of these lipid fractions was inhibitory even in their lowest tested concentrations against all the selected food pathogens; there are no reports on time-kill studies of such lipid fractions (including for Vibrio species); these novel results also confirm the possibility of using these lipid fractions in food matrices that are likely to be contaminated by tested pathogens; there is no previously published report which discusses the time-kill assay against selected Vibrio species, and there is no report on the antibacterial action in such low concentration used in this research, i.e. $62.5 \mu \mathrm{g} / \mathrm{mL}$.

\section{CONCLUSION}

The antibacterial activity of eight different lipid fractions against five foodborne pathogens was determined and equated in this research. The lipid fraction of coriander seed extracted by methanol showed the lowest total viable count when assayed against Listeria monocytogenes ATCC 13932 after 24 
h of incubation. The evaluation of cellular constituent release showed that lipid fractions disrupted the integrity of cellular envelope, causing the lysis of microbes with the highest values observed for Listeria monocytogenes ATCC 13932 when treated with methanolic extract of lipid fraction of bay leaf. SEM images also illustrated the antibacterial potential of the tested lipid fractions at $18 \mathrm{~h}$ of incubation. In conclusion, lipid fractions can effectively function against both tested Gram-positive and Gram-negative isolates even at lowest concentrations. More explanatory research is required to determine the potential of the selected lipid fractions in food matrices.

\section{ACKNOWLEDGMENTS}

The authors wish to express gratitude to Mrs Aneela Saqib for providing technical assistance in conducting this study. This research did not obtain any monetary support from funding agencies in the public, commercial, or not-for-profit sectors.

\section{REFERENCES}

1. Mandal PK, Biswas AK, Choi K, Pal UK. Methods for rapid detection of foodborne pathogens: An overview. Am J Food Technol. 2011;6(2):87-102.

https://doi.org/10.3923/ajft.2011.87.102

2. Carrasco E, Pérez-Rodríguez F, Valero A, García-Gimeno R, Zurera G. Growth of Listeria monocytogenes on shredded, readyto-eat iceberg lettuce. Food Control. 2008; 19(5):487-94. https://doi.org/10.1016/j.foodcont.2007.05.014

3. Gutierrez J, Bourke P, Lonchamp J, Barry-Ryan C. Impact of plant essential oils on microbiological, organoleptic and quality markers of minimally processed vegetables. Innov Food Sci Emerg Technol. 2009;10(2):195-202.

https://doi.org/10.1016/j.ifset.2008.10.005

4. Xu W, Qu W, Huang K, Guo F, Yang J, Zhao H, Luo YB. Antibacterial effect of grapefruit seed extract on food-borne pathogens and its application in the preservation of minimally processed vegetables. Postharvest Biol Technol. 2007;45(1):126-33.

https://doi.org/10.1016/j.postharvbio.2006.11.019

5. Cobo Molinos A, Abriouel H, López RL, Omar NB, Valdivia E, Gálvez A. Enhanced bactericidal activity of enterocin AS-48 in combination with essential oils, natural bioactive compounds and chemical preservatives against Listeria monocytogenes in ready-to-eat salad. Food Chem Toxicol. 2009;47(9):2216-23.

https://doi.org/10.1016/j.fct.2009.06.012

6. Tiwari BK, Valdramidis VP, O'Donnell CP, Muthukumarappan K, Bourke P, Cullen PJ. Application of natural antimicrobials for food preservation. J Agric Food Chem. 2009;57(14):5987-6000. https://doi.org/10.1021/jf900668n

7. Tajkarimi MM, Ibrahim SA, Cliver DO. Antimicrobial herb and spice compounds in food. Food Control. 2010;21(9):1199-218. https://doi.org/10.1016/j.foodcont.2010.02.003
8. Shan B, Cai YZ, Brooks JD, Corke H. The in vitro antibacterial activity of dietary spice and medicinal herb extracts. Int J Food Microbiol. 2007;117(1):112-9.

https://doi.org/10.1016/j.jjfoodmicro.2007.03.003

9. Chien PJ, Sheu F, Yang FH. Effects of edible chitosan coating on quality and shelf life of sliced mango fruit. J Food Eng. 2007;78(1):225-9.

https://doi.org/10.1016/j.jfoodeng.2005.09.022

10. Shan B, Cai YZ, Brooks JD, Corke H. The in vitro antibacterial activity of dietary spice and medicinal herb extracts. Int J Food Microbiol. 2007;117(1):112-9.

https://doi.org/10.1016/j.jfoodmicro.2007.03.003

11. Donsì F, Annunziata M, Sessa M, Ferrari G. Nanoencapsulation of essential oils to enhance their antimicrobial activity in foods. LWT - Food Sci Technol. 2011;44(9):1908-14. https://doi.org/10.1016/j.lwt.2011.03.003

12. Cheikh-Rouhou S, Besbes S, Hentati B, Blecker C, Deroanne C, Attia H. Nigella sativa L.: Chemical composition and physicochemical characteristics of lipid fraction. Food Chem. 2007;101(2):673-81.

https://doi.org/10.1016/j.foodchem.2006.02.022

13. Naeem A, Abbas T, Ali TM, Hasnain A. Inactivation of food borne pathogens by lipid fractions of culinary condiments and their nutraceutical properties. Microbiol. Res. 2018;9(1) (in press).

https://doi.org/10.4081/mr.2018.7465

14. Hsouna AB, Trigui M, Mansour RB, Jarraya RM, Damak M, Jaoua S. Chemical composition, cytotoxicity effect and antimicrobial activity of Ceratonia siliqua essential oil with preservative effects against Listeria inoculated in minced beef meat. Int J Food Microbiol. 2011;148(1):66-72. https://doi.org/10.1016/j.jfoodmicro.2011.04.028

15. Di Pasqua R, Betts G, Hoskins N, Edwards M, Ercolini D, Mauriello $\mathrm{G}$. Membrane toxicity of antimicrobial compounds from essential oils. J Agric Food Chem. 2007;55(12):4863-70. https://doi.org/10.1021/jf0636465

16. IBM Downloading IBM SPSS Statistics 24, Armonk, NY, USA. Available from: http://www01.ibm.com/support/docview. wss?uid=swg24041224.

17. Sandri I, Zacaria J, Fracaro F, Delamare APL, Echeverrigaray S. Antimicrobial activity of the essential oils of Brazilian species of the genus Cunila against foodborne pathogens and spoiling bacteria. Food Chem. 2007;103(3):823-8. https://doi.org/10.1016/j.foodchem.2006.09.032

18. Brahmi F, Madani K, Dahmoune F, Rahmani T, Bousabaa K, Oukmanou S, Chibane M. Optimization of solvent extraction of antioxidants (phenolic compounds) from Algerian mint (Mentha spicata L.). Pharmacogn Commun. 2012;2(4):72-86.

https://doi.org/10.5530/pc.2012.4.10

19. Zhou S, Hou Z, Li N, Qin Q. Development of a SYBR Green I real-time PCR for quantitative detection of Vibrio alginolyticus in seawater and seafood. J Appl Microbiol. 2007;103(5):1897-906.

https://doi.org/10.1111/j.1365-2672.2007.03420.x 
20. O'Grady J, Sedano-Balbás S, Maher M, Smith T, Barry T. Rapid real-time PCR detection of Listeria monocytogenes in enriched food samples based on the ssrA gene, a novel diagnostic target. Food Microbiol. 2008;25(1):75-84.

https://doi.org/10.1016/j.fm.2007.07.007

21. Negi PS. Plant extracts for the control of bacterial growth: Efficacy, stability and safety issues for food application. Int J Food Microbiol. 2012;156(1):7-17.

https://doi.org/10.1016/j.jjoodmicro.2012.03.006

22. Moghimi R, Ghaderi L, Rafati H, Aliahmadi A, McClements DJ. Superior antibacterial activity of nanoemulsion of Thymus daenensis essential oil against E. coli. Food Chem. 2016;194:410-5.

https://doi.org/10.1016/j.foodchem.2015.07.139

23. Pinto E, Vale-Silva L, Cavaleiro C, Salgueiro L. Antifungal activity of the clove essential oil from Syzygium aromaticum on Candida, Aspergillus and dermatophyte species. J Med Microbiol. 2009;58(11):1454-62.

https://doi.org/10.1099/jmm.0.010538-0

24. Kohanski MA, Dwyer DJ, Collins JJ. How antibiotics kill bacteria: From targets to networks. Nat Rev Microbiol. 2010;8(6):423-35.

https://doi.org/10.1038/nrmicro2333
25. Bajpai VK, Al-Reza SM, Choi UK, Lee JH, Kang SC. Chemical composition, antibacterial and antioxidant activities of leaf essential oil and extracts of Metasequioa glyptostroboides Miki ex Hu. Food Chem Toxicol. 2009;47(8):1876-83.

https://doi.org/10.1016/j.fct.2009.04.043

26. Gao C, Tian C, Lu Y, Xu J, Luo J, Guo X. Essential oil composition and antimicrobial activity of Sphallerocarpus gracilis seeds against selected food-related bacteria. Food Cont. 2011;22(3-4):517-22.

https://doi.org/10.1016/j.foodcont.2010.09.038

27. Paul S, Dubey RC, Maheswari DK, Kang SC. Trachyspermum ammi (L.) fruit essential oil influencing on membrane permeability and surface characteristics in inhibiting foodborne pathogens. Food Control. 2011;22(5):725-31. https://doi.org/10.1016/j.foodcont.2010.11.003

28. Sharma A, Bajpai VK, Baek KH. Determination of antibacterial mode of action of Allium sativum essential oil against foodborne pathogens using membrane permeability and surface characteristic parameters. J Food Saf. 2013;33(2):197208.

https://doi.org/10.1111/jfs.12040 